\section{U.N.E.S.C.O. Field Scientific Officer for Far East}

Mr. JAN SMID has been appointed field science co-operation officer for East Asia and the Philippines of the United Nations Educational, Scientific and Cultural Organisation. He will leave shortly for Nanking. He is a Czechoslovak civil engineer, thirtyfive years of age, who studied at the Polytechnic at Prague, and then worked in Paris, during 1937 and 1938, at the École des Ponts et Chaussées. Joining the Czechoslovak Army in France in 1939, he was wounded. In 1942, he made his way to Britain, via North Africa, and rejoined the Czechoslovak Army, serving until 1946, when he returned to Paris to work in the office of Prof. Caquot, the well-known French civil engineer, for whom he had previously worked during the period 1937-39. The Field Science Co-operation Office at Nanking is the third which U.N.E.S.C.O. has set up -the other two being at Rio de Janeiro and Cairo; the creation of a fourth, in India, will be proposed at the next General Conference of U.N.E.S.C.O., which meets in Mexico City next month. The function of these centres of scientific co-operation is to make available, in areas where the need is especially felt, information and help on scientific matters otherwise obtainable only with great delay or difficulty.

\section{British Council Science Officer for China}

Dr. H. V. WALters, chief physicist at Messrs. Dufay-Chromex, Ltd., has been appointed British Council science officer for China. He will be working with Dr. R. A. Silo, director of the British Council's Science Office in China. Dr. Walters, who is thirty years old, obtained his B.Sc. degree in 1938 while at the Imperial College of Science and Technology, London, and with a grant from the Medical Research Council remained at the College for a further year working with Dr. W. D. Wright on colour vision. In 1941 he joined Messrs. Dufay-Chromex, Ltd., becoming chief physicist in 1944, when he was placed in charge of research work on colour and optics, and of filter developments and photographic testing. In the same year he obtained his Ph.D. for papers on the trichromatic theory of vision and the spectral sensitivity of the fovea and extra-fovea.

\section{United Nations Organisation}

THE British Society for International Understand. ing (Benjamin Franklin House, 36 Craven Street, London, W.C.2) has published in its British Survey (7, No. 14. 6d.) a teacher's guide to the United Nations. This guide explains the organisation and membership of the body and reminds readers of its purposes as set forth in the original charter signed at San Francisco in April 1945. The vital Security Council, which embodies the final aim of the whole organisation, has not yet found an acceptable plan for the use of armed forces to prevent or resist a breach of the peace. The Great Power veto is the crucial problem that faces the United Nations. So far, Great Britain has not used the veto, but the Soviet Union has done so repeatedly. The pamphlet contains a clear account of the powers of the Security Council and some of the problems that confront it. Another section gives brief accounts of the fate of issues that have already been placed before the Security Council with greater or less success. Finally, there is some account of the work of the Trusteeship Council and the various economic and social agencies of the Council; here some progress has been made. The pamphlet deserves a wide circulation.

\section{Supersonic Speed Flight Investigation}

BRITISH experiments upon supersonic speed flight, using rocket-propelled aircraft, were commenced on October 8, when a Vickers radio-controlled plane was flown at St. Eval, Cornwall. It was launched frcm a 'Mosquito' at about $35,000 \mathrm{ft}$. altitude, flew for $90 \mathrm{sec}$ and dived into the sea, according to plan. Information upon its behaviour was obtained by a technical observer watching from the launching 'Mosquito', photographs taken by a 'Meteor' jet-propelled aircraft, and radio signals upon speed, accelerations, pressures, etc., sent out automatically from transmitting apparatus on the experimental aircraft itself. It was hoped that a speed of more than 800 miles an hour would be attained, the speed of sound at that height being approximately 760 miles an hour. The results, mostly mechanically recorded for accuracy and to allow of working them out at leisure, will take about a week to analyse, but it is thought that the desired speed was reached.

The experiment was not entirely successful as the machine lost height more rapidly than was anticipated, probably due to what appeared to the observer to be instability in control. It was hoped that it would have climbed after its rocket engine commenced to function. Nevertheless, it will supply much valuable informa. tion, and has proved that this technique for such investigations is possible. Improvements in the design of further experimental aircraft, as a result of the analysis of these experiments, should make it possible to continue with radio-controlled aircraft without risk to human life.

\section{Plant and Soil}

AN international periodical entitled Plant and Soil is to be issued towards the end of this year. It is to be devoted to the study of plant nutrition, plant chemistry and the related subjects of soil science, soil microbiology and soil-borne plant diseases. To meet the increasing demand for intensive crop production all over the world, quick exchange of the results of scientifiç research between the workers in this field is necessary ; a number of outstanding scientific workers from different countries have therefore decided to collaborate in establishing the new journal. The editorial board includes the names of Gäumann (Zurich), Lundegårdh, Penningby and Melin (Uppsala), Hoagland (Berkeley), Koningsberger (Utrecht), Waksman (New Brunswick), Westerdijk (Baarn), and Virtanen (Helsinki). The journal will be published by the Martinus Nijhoff Publishing Company, The Hague. The subscription price is 7.50 dollars a year for one volume containing about 400 pages (four parts). Original contributions in English, French or German should be sent to the secretary of the Board of Editors, Dr. E. G. Mulder, Agricultural Experiment Station, Eemskanaal ZZ. 1, Groningen, Holland.

\section{R.C.A. Technical Papers}

THE R.C.A. Review (Radio Corporation of America, R.C.A. Laboratories Division, Princeton, New Jersey) has recently issued volume 1 and volume $2 a$ of the Index to R.C.A. Technical Papers. Volume l covers the years 1919-45, and $2 a, 1946$. It is planned to publish the yearly indexes, of which $2 a$ is the first, as sub-volumes, consolidating them under one cover at the end of five years as "R.C.A. Technical Papers" (1946-1950)-Index-Volume 2". Volume 1 supersedes "Index-Technical Papers by R.C.A. Engineers (1919-1939)" published by R.C.A. Institutes Tech- 